\title{
School Experience During Adolescence: A Comparative Study Between Adolescent Offenders and Not Offenders
}

\author{
Jorge Luiz da Silva \\ Marina Rezende Bazon ${ }^{2}$ \\ ${ }^{1}$ Universidade de Franca, Franca, SP \\ ${ }^{2}$ Universidade de São Paulo, Ribeirão Preto, SP
}

\begin{abstract}
This study aimed to test the school control model, inherent to the Social and Personal Control Theory, verifying which context variables and mechanisms would distinguish offender adolescents from non-offenders adolescents, aiming to understand their school experience. Sixty male adolescents $(15$ school-dropouts-offenders/15 student-offenders, 15 school-dropouts-nonoffenders/15 students-non-offenders), aged 14 to 18 participated ( $M=16,6 ; S D=0,78)$. All responded a scale formulated in the light of the theoretical framework. Data were analyzed by the Kruskall-Wallis test, with Dunn post-test. The results showed that everyone would be to some extent vulnerable to negative school-experience, depending on the context variables, and also indicated that "performance" and "school-bond" would be more associated with school-dropout, while "school constraints" with involvement in infractions. The identification of these problematic aspects in the schooling of the offender adolescents helps to think about the interventions, in the socio-educational accompaniment, aiming at an adequate (re)insertion in the school. Keywords: adolescent offenders; school; school adjustment
\end{abstract}

\section{A Experiência Escolar Na Adolescência: Estudo Comparativo Entre Adolescentes Judicializados e Não-Judicializados}

\section{Resumo}

Este estudo objetivou testar o modelo da regulação escolar, inerente à Teoria da Regulação Social e Pessoal da Conduta, verificando quais variáveis de contexto e mecanismos distinguiriam significativamente adolescentes infratores de não infratores, visando à compreensão de sua experiência escolar. Participaram 60 adolescentes do sexo masculino (15 infratores-evadidos/15 infratores-estudantes, 15 não infratores evadidos/15 não infratores estudantes), com idades entre 14 e 18 anos $(M=16,6 ; D P=$ $0,78)$. Todos responderam a uma Escala formulada à luz do referencial teórico. Os dados foram analisados pelo teste de Kruskall Wallis, com pós-teste de Dunn. Além de mostrar que todos seriam, em alguma medida, vulneráveis a uma experiência escolar negativa, em função das variáveis de contexto, os resultados também indicaram que "desempenho" e "vínculo escolar" estariam mais associados à evasão, e "constrangimentos escolares" ao envolvimento em atos infracionais. A identificação destes aspectos problemáticos na escolaridade dos adolescentes infratores ajuda a pensar as intervenções, no escopo do acompanhamento socioeducativo, visando uma adequada (re)inserção escolar.

Palavras-chave: adolescente em conflito com a lei, escola, ajustamento escolar

\section{Experiencia Escolar en Adolescencia: Un Estudio Comparativo entre Adolescentes con juicios y sin juicios}

\section{Resumen}

Este estudio tuvo como objetivo comprobar el modelo de regulación escolar, inherente a la Teoría de Regulación Social y Personal de la Conducta, verificando que variables de contexto y mecanismos distinguirían significativamente adolescentes infractores de no-infractores, buscando la comprensión de su experiencia escolar. Participaron 60 adolescentes de sexo masculino (15 infractores-evadidos/15 infractores-estudiantes, 15 no-infractores-evadidos/15 no-infractores-estudiantes), con edades entre 14 y 18 años $(M=16,6 ; \mathrm{DP}=0,78)$. Todos respondieron una Escala basada en referencial teórico. Los datos fueron analizados por el test de Kruskall-Wallis Test y Post-Test de Dunn. Además de mostrar que todos serían, en alguna medida, vulnerables a una experiencia escolar negativa, en función de las variables de contexto, los resultados también indicaron que "desempeño" y "vínculo escolar" estarían más asociados a evasión y "constreñimientos escolares” y a participación en actos de infracción. La identificación de estos aspectos problemáticos en la escolaridad de los adolescentes infractores ayuda a pensar en las intervenciones, en el objetivo de acompañamiento socio-educativo, buscando una adecuada (re)inserción escolar. Palabras-clave: adolescente en conflicto con la ley, escuela, ajuste escolar

\section{Introduction}

Schools are an important environment of socialization and learning for adolescents. At school, they invest a good part of their daily time, interacting with teachers and colleagues and participating in activities, which promotes cognitive, and social and emotional development (Calejon, 2017; Silva \& Bazon, 2014). Adolescent offenders seem to have a predominantly negative school experience, which is reflected in poor performance and high dropout rate (Calejon, 2017; Cunha \& Dazzani, 2016; Silva, Cianflone, \& Bazon, 
2016). In 2011, in Brazil, 57\% of adolescent offenders deprived of liberty evicted from school at the time of apprehension, and 8\% were not literate (National Council of Justice, CNJ, 2012). These rates contrast with those of the general adolescent's population in the same year, which indicate that 3,1\% wasn't at school and 1,9\% were not literate (Brazilian Institute of Geography and Statistics - IBGE, 2012). In this scenario, a better understanding of the school experience can generate significant subsidies for planning and implementation of interventions to improve the adolescents schooling, especially those with higher difficulties, which seems to be the case of those adolescent offenders (Bazon, Silva, \& Ferrari, 2013).

From a theoretical point of view, the Social and Personal Control Theory of Deviant Behavior (LeBlanc, 1996, 2003, 2006) helps to understand the aspects related to emergence and maintenance of conduct against the law, in the different contexts of youth socialization. Regarding the school, it focuses on variables related to criminal conducts and the relationships between them, based on structural data analyzes of a large sample of adolescents from the general population and adolescents prosecuted for infractions in the city of Montreal, Canada.

Thus, a system is established regarding the control of conduct "in and by the school" (Figure 1), in which three main interdependent mechanisms are articulated: "school performance", "school bonding", and "school constraints". These operate under the conditions established by the following context variables, "school record" (existence or not of delays/age-series mismatch), "parental schooling" and "stress" (associated to school experiences) (LeBlanc, 1997; 2003) In conceptual terms, it is worth clarifying that the concept of mechanisms refers to elements and processes effectively responsible for individual behavior, which is dynamic by their very nature, explaining variations in behavior over time. Context variables, in turn, refers to elements that compose the environment, affecting individual behavior only because of the impact they have on the mechanisms (Mannheim, 1971).

The "performance" (measured by the school results) occupies a prominent position in the control system. According to LeBlanc (1997), the quality of the performance constitutes a foundation of school control. When it's high, favors the investment in academic activities - classes and tasks/assignments, and participation in school activities and disciplines.

The "school bond", in turn, is based on three components: 'Attachment to teachers,' 'investment in schooling' and 'commitment to education.' To summarize, 'attachment' represents the student's relationship with his teachers, permeated by positive affects. Based on the affective identification with the teachers, on good a communication between them regarding the contents of the classes, as well as, on the feeling of security experienced by the student, regarding the fact

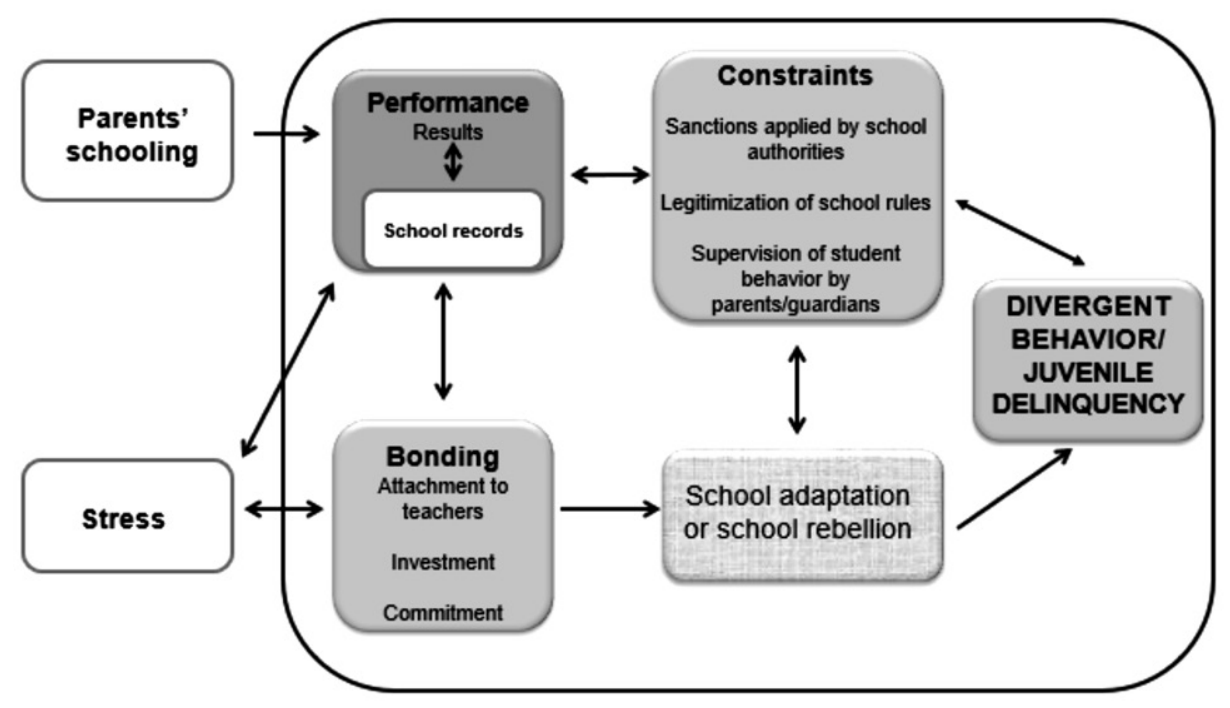

Source: LeBlanc, 1997

Figure 1. School Control scheme 
of being able to get help when facing difficulties related to the contents. "Investment" corresponds to the time that is dedicated to studies, with the feeling of being competent or not, coupled with the conception of doing one's best at school. The level of investment in school activities is reinforced by good academic performance and attachment to teachers, and this type of investment seems to compete for investments in school activities either. The 'commitment,' represents what the student establishes for himself concerning schooling, the commitment that makes frequency at school and study (the accomplishment of tasks and jobs) an internalized obligation. Commitment, thus, is negatively related to dropout. It is necessary to consider that the 'commitment' depends on the students' perception of their school competences, on how much they think they are competent or not to school demands. Becoming competent promotes a positive attitude towards school/schooling, which is essential in determining expectations regarding the duration of studies. 'Commitment' is strongly associated with 'attachment to teachers,' both of which influence and are influenced by 'school investment.' The components of school bonding are small parts of a bigger system, the school control (LeBlanc, 1997; 2003).

The mechanism "school constraints," in turn, refers to the rules and "sanctions applied by school authorities" to behaviors considered inappropriate to the context of the school, as well as the supervision of student behavior by parents/guardians. "School constraints" also involve an internalized dimension that can be gauged through indicators relating to the "legitimization of school rules by the adolescent," meaning they took the school rules for themselves. The more consolidated the 'internal constraints,' less necessary are the external ones (appeal to rules and application of sanctions). External constraints, however, when overused, signs a process of "maladaptation," which may encourage different behaviors and gradual school disintegration (LeBlanc, 1997, 2006).

Regarding the contextual variables, a "record" that includes delay, producing age-series lags, indicates a possible presence of learning difficulties, providing worse conditions to "school performance." "Parents" schooling", in turn, can provide an indication of the value of education in the family, not only by the model of parents/guardians offered, but also the incentive and performance, the school commitment of the children, as well as, the offer of aid for the accomplishment of the school tasks/works (Le Blanc, 2003). As for "stress," if present in a particular student, this stems from the perception of being overcharged and/or monitored by the teachers, and from the fear of failure in school. High levels of stress impair learning, "performance" and relationship with the teachers, leading to poorer conditions for "attachment" to these figures and, consequently, to the development of "school bonding” (LeBlanc, 1997).

In addition to school experience, LeBlanc (2003) emphasizes that other characteristics of the school as an institution should also be considered as risk factors associated with the infraction conduct in this area. However, the way teens act and react to the school environment is a relevant issue that can affect their behavior both in and out of school.

LeBlanc $(2003,2006)$ emphasizes that investigations on the relationship between school experience and juvenile delinquency are less numerous when compared, for example, to those that focus on aspects of family functioning. The evidence, derived from research carried out through different methods and in different sociocultural contexts, is in line with the propositions inherent in the Theory of Control of Conduct "in and by the school." They indicate that school experience characterized by low performance (Calejon, 2017) and delay (associated with a sense of incompetence and lack of motivation) (Bazon et al., 2013), low investment in school activities, absenteeism and dropout educational aspirations) (Destro \& Souza, 2012; Silva et al., 2016), denote school dissociation. Similarly, they indicate that students' difficulties in interacting with peers and teachers (Bazon et al., 2013) and the fact that they are often punished by the school (Cornell, 2013; Esterle-Hedibel, 2006), are associated risk factors conduct. Some studies demonstrated that negative school experience is one of the most important predictors of juvenile offender involvement (Geib, Chapman, D’Amaddio, \& Grigorenko, 2011; Zhang et al., 2010).

Given the presented, the overall objective of this study was to test the school control model in a Brazilian sample, verifying which context variables and mechanisms would significantly distinguish adolescents who were offenders, who were prosecuted due to the committal of infractions, from adolescents with no criminal records. The results will provide support to understand the adolescents' school experience and clues to the problem of involvement in infractions, which may help in planning socio-educational interventions. 


\section{Method}

\section{Participants}

The convenience sample, composed of 60 male adolescents, aged 14 to 18 years $(\mathrm{M}=16.6$ years, SD $=0.78$ years), was formed according to the following criteria: "offender" (having been tried/sanctioned in a socio-educational measure); "non-offender" (no issues with the Justice System); "student" (attending regularly to the school); "out of school" (out of school for at least a year).

According to these criteria, four sample groups, each one with 15 participants, were established, adolescent offenders who dropped out of school (O-Drop); adolescent offender students (O-S); adolescent non-offenders who dropped out of school (NO-Drop); adolescent non-offender students (NO-S). All the participants study or had studied in public schools. The average time away from school for the groups of dropout adolescents was 2.07 years for offenders (O-Drop) and 1.93 years for non-offenders (NO-Drop). It is worth mentioning that they lived in the neighborhoods of Ribeirão Preto city (São Paulo state), with similar socioeconomic characteristics. In all the groups the majority belonged to class $\mathrm{C}$ families (O-Drop $=73.7 \%$, O-S $=60.3 \%$, NO-Drop $=67 \%$, NO_S $=$ $53.6 \%$ ), according to Brazil Economic Classification (ABEP, 2010), with average income ranging between 1,000 and 1,500 reais.

Every adolescent offenders (O-S and O-Drop) were on an assisted liberty probation. Regarding violations, the police records of the judicial remedy (Assisted liberty), indicated mainly drug traffic (61.7\%) and robbery $(25.0 \%)$. In minor proportions, 3,4\% of the adolescents were convicted by threat, and $1,7 \%$ by bodily injury. However, $8.6 \%$ of the reports did not specify the kind violation practiced.

\section{Instrument}

The Portuguese version of the School Scale, belonging to the Measuring Adolescent Social and Personal Adaptation - Québec - MASPAQ (LeBlanc, 2003) was used, it is based on the Social and Personal Control Theory of Deviant Behavior. The MASPAQ was developed over 30 years of longitudinal research and refers to a set of instruments questionnaires/ scales/inventories aimed to investigate the social and personal adaptation of adolescents (from any gender), by interpreting their own experience with family, in school, with their pairs, their activities, and their beliefs. The alphas related to the consistency analysis of the various instruments inherent to the MASPAQ varied from 0,64 to 0,91, with the School Scale in 0.73 (LeBlanc, 2003).

The instrument aims to obtain information from the adolescent, assuming that the essential information to understand are their interactions in the school derives from their perception of this environment. Although this source of data may involve distortions of reality, memory failures, and personal interpretations, it refers to the most basic and relevant material in the research of this public (LeBlanc, 2003). Thus, his questions allow a comprehensive assessment on how the adolescent perceives the school and how it adjusts to this system of control of their conduct. The School Scale is composed of 68 questions that seek information regarding the elements/dimensions that constitute the mechanisms and the context variables that make up the model of the control of conduct in and by the school.

Some examples of the questions: "School record (lag/delay)" - Did you flunk in one or more years in elementary school (1st to 4 th grade / 1 st to 5 th grade)? "Parent/Guardian Schooling" - Until what year did your father/mother studied? "School stress" - Do you feel nervous and tense, "stressed out" at school?; "Performance" - Regarding your grades, how do you see yourself compared to other students in your class/ school at your age? "School Bond" - "Investment" Usually, how many hours a day do you spend(spent) doing your homework, lessons, and research at school and home?; 'Commitment' - How important is it for you to have good grades?; 'Attachment' - Do you feel close to your teachers and do you rely on them?; "School Constraints" - Have you ever been suspended from school (a few days or more)? / In general, when your parents are not happy with your grades, what do they do ?. The questions usually require answers on a five-level Likert scale. Some questions, such as those on Investment and School Constraints, are open-ended, like the examples above. Those answers can be categorized.

The School Scale was adapted to Brazilian Portuguese with the authorization of its author, based on procedures for translation, back translation and semantic adequacy in a pilot study carried out with adolescents with a sociodemographic background similar to the population focused on the study (offenders and non-offenders). More details on this procedure are found in Silva (2013). This stage of semantic adaptation included 
procedures of validation of the School Scale to include the psychometric data for the Brazilian population.

\section{Procedure}

The study project was submitted to and approved by the Institutional Review Board at the Faculdade de Filosofia, Ciências e Letras de Ribeirão Preto, Universidade de São Paulo (FFCLRP-USP), according to Process CEP No. 579/2011 - 2011.1.1321.59.8. The total sample of the study (offenders and non-offenders, students or dropout students) was recruited for convenience, according to the mentioned criteria, in the context of different institutions in the city of Ribeirão Preto-SP.

The adolescent offenders, students, and dropout students (O-S and O-Drop), were recruited in four institutions that maintained programs of socio-educational measures in open means (Assisted Freedom). To recruit non-offending students (NO-S), we resorted to a public school. In order to recruit adolescent non-offenders who dropped out of school (NO-Drop), the municipality's Child Protective Council (Conselho Tutelar) was used to access a list of non-offending student/adolescent names that had dropped out. Upon authorization provided by the Child Protective Council, adolescents mentioned in the list were sought, by phone or in person, to participate in the survey. This procedure was carried out until the desired number of adolescents was reached $(n=15)$, considering that some were not found and others were not authorized by their parents/guardians and/or refused to cooperate with the study.

The institutions responsible for the programs of Assisted Freedom had to authorize the recruitment of adolescents, as well as, the Public School authorized the data collection on their premises. Part of the time allocated to the weekly socio-educational services, in the case of Assisted Freedom programs, and part of the class schedule, in the case of the school, making available a reserved room for this purpose. Regarding the adolescent non-offenders who dropped out of school, the data collection was carried out in their residences. The privacy of this subgroup was preserved by conducting the interviews in private places. Therefore the School Scale was applied individually, with each adolescent, in the form of a structured interview, during 30 minutes approximately. The information on the offenses committed by the adolescent offenders, as mentioned above, was obtained through police and medical records.

\section{Data analysis}

The answers provided to the instrument were included in a computerized correction program inherent to MASPAQ - Maspaq Général 2.0 pour Windows (LeBlanc, 2003), which provided the raw scores of each participant. The scores obtained were statistically treated, and descriptive analyzes and comparisons between the groups were performed using the Kruskall-Wallis test, a non-parametric technique to compare two or more groups. Therefore it does not require assumptions about the distribution of the data. Later, the Dunn's test was used to obtain more detailed results, since it allows to identify the groups presenting significant differences, one about the others. The analyzes were carried out using software $\mathrm{R}$ version 2.14. The significance level of 0,05 was considered for all tests.

\section{Results}

The results summarized in Tables 1 and 2 present the mean values obtained by the adolescents of the different groups, as well as the results of the statistical comparisons performed by Kruskall-Wallis test, which identified the existence or not of significant differences in the comparison between all the groups through the value of p. Dunn's test, on the other hand, identified as true or false the existence of significant differences at a more detailed level combining the groups two by two. Table 1 shows the context variables results.

Regarding the context variables, concerning "school record - delays/age-series delays," it is emphasized that the two groups constituted by adolescent offenders presented the highest averages, and O-S presented a higher number of failures, compared to O-Drop. In contrast, groups of non-offending adolescents (NO-Drop and NO-S), although exhibiting some school delay, obtained lower mean values. However, a statistically significant difference $(p<0.05)$ was found only between the O-Drop and NO-S groups. Regarding "parents/guardians' schooling," it should be highlighted that among the adolescents non-offenders, there was a higher level of schooling between the parents. However, among the six comparisons, only the one referring to the O-Drop and NO-S groups presented a significant difference $(\mathrm{p}<0.05)$. The results concerning "school stress" showed variations in the groups with a higher mean in the O-S group, rather than the O-Drop group, which presented lower mean. The significant difference $(\mathrm{P}<0.05)$ was only true for two comparisons: between O-Drop and O-S, and between O-Drop 
Table 1

Results of the comparisons between the groups regarding the contextual variables of the School Control

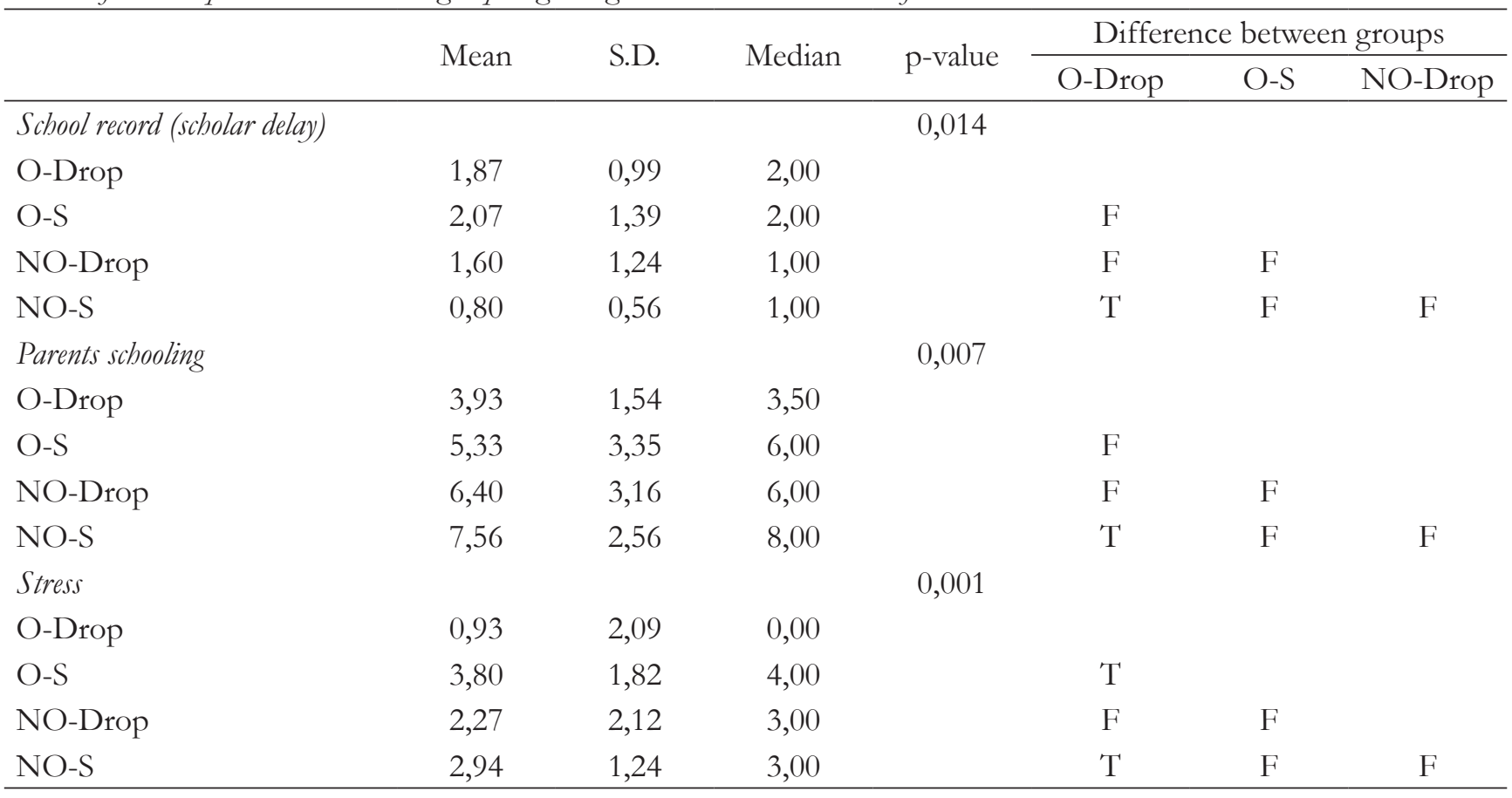

Note $*_{p}<0,05$; S.D. = standard deviation; adolescent offenders who dropped out of school (O-Drop); adolescent offender students (O-S); adolescent non-offenders who dropped out of school (NO-Drop); adolescent non-offender students (NO-S); F = false and T = true, related to the significant statistical difference between the groups.

and NO-S. Table 2 presents the results regarding the mechanisms of School Control.

Regarding the "performance," the results showed that students (O-S and NO-S), on average, perform better than the students (O-Drop and NO-Drop). The comparison between the groups revealed the existence of statistical differences in some of them. The O-S group was statistically different from O-Drop $(\mathrm{p}<0.05)$, presenting a better performance. The O-S group also shown better results than NO-Drop $(\mathrm{p}<0,05)$. This group (NO-Drop), in turn, presented inferior performance than NO-S group ( $\mathrm{p}<0.05)$. The NO-S group presented a better performance than O-Drop $(\mathrm{p}<0.05)$.

Regarding "school bonding" it is evaluated by the results of the following components: "investment," "attachment to teachers," and "performance." The adolescent non-offender students, in general, presented the highest means when compared to the dropouts, considering the data they submitted before quitting school. However, the comparisons indicated significant differences $(\mathrm{p}<0.05)$ only between the groups composed of the offenders (O-Drop and O-S) and between O-Drop and NO-S in three linkage components.
Regarding the "constraints" results, there was a statistically significant difference between the groups $(p<0.001)$ in the variable "school sanctions," indicating that the juvenile offenders were on average more punished by the school authorities as compared to non-offenders. The differences found were statistically significant $(p<0.05)$ in the comparison between the O-Drop and NO-Drop groups, and between O-Drop and NO-S. Likewise, there were differences between O-S group and the two groups of non-offending adolescents (NO-Drop and NO-S). Regarding the 'parental supervision' component, the highest average was found in the O-S group, signaling greater monitoring and care about frequenting school and the dedication to studies for adolescents in this group. The comparisons indicate significant differences $(p<0.001)$ between the groups composed of the offenders (O-Drop and O-S) and between O-Drop and NO-S $(\mathrm{p}<0,05)$.

\section{Discussion}

This study aimed to verify which contextual variables and mechanisms of School Control inherent 
Table 2

Results of the comparisons between the groups regarding the mechanisms of School Control

\begin{tabular}{|c|c|c|c|c|c|c|c|}
\hline & Mene & $S \mathrm{D}$ & Medion & Prollo & Differ & betw & groups \\
\hline & Miean & S.D. & Median & p-value & O-Drop & $\mathrm{O}-\mathrm{S}$ & NO-Drop \\
\hline Performance & & & & & & & \\
\hline O-Drop & 1,57 & 3,23 & 0,00 & 0,001 & & & \\
\hline $\mathrm{O}-\mathrm{S}$ & 6,40 & 2,29 & 7,00 & & $\mathrm{~T}$ & & \\
\hline NO-Drop & 3,13 & 3,07 & 4,00 & & $\mathrm{~F}$ & $\mathrm{~T}$ & \\
\hline NO-S & 6,44 & 2,06 & 7,00 & & $\mathrm{~T}$ & $\mathrm{~F}$ & $\mathrm{~T}$ \\
\hline School bonding & & & & & & & \\
\hline Investment & & & & 0,001 & & & \\
\hline O-Drop & 1,50 & 2,98 & 0,00 & & & & \\
\hline $\mathrm{O}-\mathrm{S}$ & 7,00 & 2,80 & 7,00 & & $\mathrm{~T}$ & & \\
\hline NO-Drop & 3,87 & 3,44 & 5,00 & & $\mathrm{~F}$ & $\mathrm{~F}$ & \\
\hline $\mathrm{NO}-\mathrm{S}$ & 6,88 & 2,42 & 7,00 & & $\mathrm{~T}$ & F & $\mathrm{F}$ \\
\hline Attachment to teachers & & & & 0,001 & & & \\
\hline O-Drop & 1,14 & 2,48 & 0,00 & & & & \\
\hline $\mathrm{O}-\mathrm{S}$ & 8,20 & 2,73 & 9,00 & & $\mathrm{~T}$ & & \\
\hline NO-Drop & 5,40 & 4,66 & 8,00 & & $\mathrm{~F}$ & $\mathrm{~F}$ & \\
\hline $\mathrm{NO}-\mathrm{S}$ & 8,13 & 2,55 & 9,00 & & $\mathrm{~T}$ & $\mathrm{~F}$ & $\mathrm{~F}$ \\
\hline Commitment & & & & 0,001 & & & \\
\hline O-Drop & 2,07 & 4,43 & 0,00 & & & & \\
\hline $\mathrm{O}-\mathrm{S}$ & 12,27 & 4,30 & 14,00 & & $\mathrm{~T}$ & & \\
\hline NO-Drop & 8,07 & 6,93 & 12,00 & & $\mathrm{~F}$ & $\mathrm{~F}$ & \\
\hline NO-S & 12,56 & 4,10 & 13,50 & & $\mathrm{~T}$ & $\mathrm{~F}$ & $\mathrm{~F}$ \\
\hline Constraints & & & & 0,001 & & & \\
\hline School sanctions & & & & & & & \\
\hline O-Drop & 1,00 & 0,00 & 1,00 & & & & \\
\hline $\mathrm{O}-\mathrm{S}$ & 1,00 & 0,00 & 1,00 & & $\mathrm{~F}$ & & \\
\hline NO-Drop & 0,00 & 0,00 & 0,00 & & $\mathrm{~T}$ & $\mathrm{~T}$ & \\
\hline $\mathrm{NO}-\mathrm{S}$ & 0,00 & 0,00 & 0,00 & & $\mathrm{~T}$ & $\mathrm{~F}$ & $\mathrm{~T}$ \\
\hline Parents monitoring & & & & 0,001 & & & \\
\hline O-Drop & 0,57 & 1,60 & 0,00 & & & & \\
\hline $\mathrm{O}-\mathrm{S}$ & 3,80 & 2,08 & 3,00 & & $\mathrm{~T}$ & & \\
\hline NO-Drop & 2,27 & 2,34 & 2,00 & & $\mathrm{~F}$ & $\mathrm{~F}$ & \\
\hline NO-S & 2,69 & 1,66 & 3,00 & & $\mathrm{~T}$ & $\mathrm{~F}$ & $\mathrm{~F}$ \\
\hline
\end{tabular}

Note ${ }^{*} \mathrm{p}<0,05$; S.D. = standard deviation; adolescent offenders who dropped out of school (O-Drop); adolescent offender students (O-S); adolescent non-offenders who dropped out of school (NO-Drop); adolescent non-offender students (NO-S); F = false and $\mathrm{T}=$ true, related to the significant statistical difference between the groups.

to the theoretical framework of Social and Personal Control Theory would distinguish significantly, adjudicated adolescents who committed infractions from adolescents without a history of infractions, to obtain subsidies to understand the school experience of the offenders and, that way, understand the problematic of the involvement in the practice of crimes. Returning to the reference adopted in the present study, its possible 
that the school experience in adolescence is linked to the mechanisms of control of conduct, in and by the school: "school performance," "school bonding," and "school constraints." Which operate under the circumstances (the context variables) - "school history - delay/ lag age-grade", "parental schooling" and "school stress" - which affect school experience indirectly.

Regarding the contextual variables, "school record" is highlighted first, emphasizing the fact that all groups analyzed were characterized by some age-series discrepancy. Understanding this characteristic as an indicator of social vulnerability, as Calejon (2017) indicates, all groups would be, therefore, be in some way vulnerable. However, the two groups who dropped out of school (O-Drop and NO-Drop) were significantly more delayed (age-grade mismatch), when compared to the two groups of adolescent students (O-S and NO-S). LeBlanc (2003) points out that school delay, due to failures and/or dropouts, leads to lack of motivation to go on with the studies, thus more directly associating to dropouts than to criminal conduct, which corresponds to the data, once school dropout rates are higher than those involved in infractions during adolescence. The relationship between dropping out of studies and juvenile offenses is certainly mediated by more specific risk factors, such as exposure to criminalized models/ affiliation with offending peers, a situation that is only present for some students who dropped out of school (Esterle-Hedibel, 2006).

It is worth noticing that fails, as the main reason for the existence of delays in schooling, became more present in NO-Drop group, contradicting the expectation, since it was expected to find more failures in the O-Drop group. It is possible that the present result can be interpreted in line with the propositions made by Bazon et al. (2013), due to the data found in a study of the school trajectories of adolescent offenders. The authors found that the adolescent's offenders who had had their school failure more institutionally recognized (higher number of failures) had less negative feelings about school compared to others that, although marked by less flunks, had progressed through series without actually realizing the learning (being aware of it). This was observed by the adolescents as lack of commitment from the school team towards them, denoting, in these cases, higher disengagement and, even, rejection to school. It is possible that the adolescents offenders, who remained connected to the school, although presenting more significant number of disapprovals (in comparison to the others), were able to deal with this situation, understanding it as a sign of the school's commitment to their learning, which would preserve a more positive feeling towards school institution.

As for "parents' schooling," in all groups, the average number of years studied was low. According to Calejon (2017), the low level of schooling of the parents/guardians is a condition linked to social status, which functions more properly as a variable of vulnerability. However, it is noted, that the lower the parents' education, the greater their association with dropouts and offender conditions, in line with the notes made by Zhang (2011), since in this respect, groups O-Drop and NO-S distinguished significantly. For LeBlanc et al. (1996), higher parental/guardian schooling can prevent and/or delay school dropout because it is roughly linked to higher expectations, the ability to offer academic help and supervision. Therefore it is thinkable that the lower the schooling, the lower the expectation, the academic help and the supervision offered by the parents/guardians. Thus, these family aspects would have a stronger influence on adolescents in the O-Drop group, which accumulates problems of school dropout and involvement in infractions, repeating the processes of social exclusion produced by the educational system from one generation to another (Calejon, 2017).

Another contextual variable influencing the conditions under which the school control mechanisms operate is the "stress" experienced by the adolescent in school. The results showed that the highest average level of stress would be in O-S group, indicating that they would have a school experience associated with tension, the feeling of being "watched" and also the fear of not being able to "perform well" in school. This result also suggests a more significant vulnerability in this group regarding the conditions in which school control takes place, considering that one way to reduce stress and frustration in school is to drop out it (Esterle-Hedibel, 2006). With slightly lower levels of stress, we have the groups formed by NO-S and NO-Drop adolescents, indicating that schooling for them represents a challenge.

Contrary to expectations, the O-Drop group had the lowest mean level of school stress, differing significantly from the offenders and non-offenders (O-S and NO-S). It is possible that O-Drop adolescents have in the past experienced high levels of stress and this might contribute significantly to school dropout. In this case, the low level of stress indicated by their responses, in the present, would be more a methodological issue, a function of the time elapsed since 
school drop-out to the time of the interview, two years on average. Although the issues on the Scale used, remind the adolescents about the resentful stress in school, while they were studying, the passage of time may affect the memory of this experience. It is also possible that, even before the school dropout, the adolescents in this group were so disassociated from the school that they no longer "care" about the potential stress-generating situations.

The experience of excessive stress can counteract the individual's abilities to deal with the challenges inherent in everyday life. In the school context, it competes for some students to perceive the demands related to learning and interpersonal relations as something that exceeds their capacity, making it difficult for school adjustment and, consequently, school bonding (Xavier \& Chaves, 2016). Thus, the stress experience certainly contributes producing conducive conditions to dropouts, through a gradual collapse promoted in the performance and the social coexistence on the school environment. Therefore it is understood, that adolescents who stop attending school, and begin to seek experiences, in other contexts, where they feel less stressed and more successful, even in non-conventional environments, through the adoption of behavior, including, the practice of crimes (Jimenez, 2014).

In summary, regarding the focused context variables, it can be stated that the adolescents of the four groups presented indicators of unfavorable conditions to school control. All of them would have, somewhat, school deficits and parents/guardians with low schooling, reflecting their social vulnerability. In all groups, the majority belong to the same socioeconomic class, class C (ABEP, 2010). This could mean that the four groups would equally suffer the social determinism associated with vulnerability, according to Esterle-Hedibel (2006). The offenders who drop out school, however, would be more vulnerable, since they would differ significantly from the others, as the most negative indicators in these two variables. Regarding school stress, however, the offenders students should present more negative indicators compared to the others, once they are more vulnerable than the others in this respect. However, the dropped out offenders, characterized by presenting less stress than others have also experienced high levels of stress in the past, once the evasion itself, that occurred on average in the last two years, a way to escape from this experience.

Thus, considering the context variables, the juvenile offenders (students and those who dropped Psico-USF, Bragança Paulista, v. 23, n. 3, p. 437-449, jul./set. 2018 out of school) constituted the groups in less favorable conditions to the mechanisms of school control "performance," "linkage" and "school constraints," becoming susceptible to impact their experience of schooling negatively. So, focusing on each of the mechanisms, it was observed that the greatest differences between the groups were in "performance". As predicted by the theoretical model, better performance was observed among the students (O-S and NO-S) and worse among the dropouts (O-Drop and NO-Drop), denoting the crucial position of this mechanism in the system of school control, especially concerning the risk of school dropout.

Although "school performance" is considered to occur in the context of a teaching-learning process, that means, in the interactions between teachers and students, as well as, in the conditions surrounding such interactions, according to the theoretical model adopted (LeBlanc, 1997), and other researchers (Destro \& Souza, 2012), it happens in terms of subjective experience as a matter of personal competence. Throughout the schooling process, the feeling of school (in) competence built up, becomes decisive regarding (non) perseveration of the studies. The results of this study suggest that the best performance in O-S is probably the variable that best explains the fact that they remain in school. In the model proposed by LeBlanc (2006), "performance" impacts school behavior through the effects it produces on "social bonding" and the "constraints" experienced in school. Therefore, to avoid school dropouts involves school bonding, which is directly and strongly affected by "performance" (Bazon et al., 2013; Sharkey et al., 2011).

The next mechanism, "school bonding," LeBlanc (2006), explains that "performance" directly contributes to strengthening or weakening, through the students' awareness of their performance compared to other students in the class, which is gradually provoking feelings of "belonging/non-belonging" to the school. Thus, if performance does not occur according to the established parameters, the connection to the school becomes fragile because throughout the years, in the absence of an appropriate pedagogical intervention, there is a decrease in the student's investment in school activities, as well as, a disqualification of the relations with the teachers, since these are also based on the effective performance in different subjects, and not only on a subjective evaluation of the student about his/her performance (Bazon et al., 2013; Silva \& Bazon, 2014). On the other hand, a good performance, representing 
effective school acquisitions, can exert a protective effect on the adolescent's school experience, mitigating the association between failure and disengagement, fostering greater interest in the contents learned and, therefore, greater investment in school activities (Desro \& Souza, 2012; LeBlanc, 2003). Regarding "school bonding," it's components - 'investment in school activities,' 'attachment to teachers' and 'school commitment'- feed one an another.

Referring specifically to 'investment,' from the School Control model perspective, as well as, in the literature, school investment is stimulated by performance, as already pointed out (LeBlanc, 2003; Silva et al., 2016). In the present study, the best investment results were found in the groups of adolescent students (O-S and NO-S), with no differences between them, but significantly different from the O-Drop group. These constituted the group with lower performance and level of school investment. In this sense, the lowest investment would have more direct relation to the variable school dropout. Low investment in school, if not associated with a situation of access the market (or any other pro-social, sports or cultural activities, for example), contributes to the increased risk of involvement of adolescents in activities of non-conventional nature, including criminal activities (to the extent that they are exposed to such influences and opportunities in the community) (Li \& Lerner, 2011).

As for 'attachment to teachers', in the School Control model, represents the existence of a relationship based on positive affection, on good communication between the parties, on an affective identification of the students to the teachers, and also on a sense of security experienced by the student, being able to count on the teachers help, if necessary, regarding school subjects. This close relation enables the school bond through the promotion of investment and commitment to schooling, contributes to reducing the necessity for "school constraints" because obedience to the rules issued by the authorities (including teachers) takes place naturally (LeBlanc, 1997, 2006). On the other hand, poor teacher-student communication contributes to little or no attachment to teachers, and together with academic failure (low performance), promotes less commitment regarding schooling, increasing the motivation to look for other activities that provide immediate rewards, including risk activities (Gomes \& Conceição, 2014 and LeBlanc, 2003).

In the present study, results concerning "attachment to teachers" denote the fragility of teacher-student relationship for the group of adolescents dropouts, especially for offenders (O-Drop). The highest "attachment" averages were observed in the two groups with no differences between them but on those grouped in O-Drop, which did not differ significantly from those grouped in NO-Drop, again denoting a more direct relation between negative indicators in the variable "school dropout", one of the "school bond" components.

Regarding the 'commitment,' lower levels, in addition to adversely affecting educational aspirations and, consequently school investment, are related to the chance to have problems in the subject schedule, experiencing constraints by the authorities (LeBlanc, 1997, 2006). In the midst of low commitment, there is a reduced engagement with the values and rules of the institution Thus; the low commitment would also have the effect of increasing disengagement through negative experiences caused by school constraints. The results of this mechanism follow the same pattern as those found in 'investment' and "attachment to teacher." The highest 'performance' averages were observed in the two groups with no differences between them but on those grouped in O-Drop, which did not differ significantly from those grouped in NO-Drop, denoting a direct relation between negative indicators in the variable "school dropout," one of the "school bond" components. So, the adolescents who drop out of school would have less commitment to education/ their schooling, assigning a small value to the school, mainly because they did not perceive themselves capable of meeting school demands (Bazon et al., 2013).

Regarding the mechanism "school constraints," it was shown that adolescent offenders (I-Es and I-Ev) were submitted to further sanctions/punishments. This may be explained by the fact that adolescent offenders have more behavioral problems than non-offenders. It is also possible that the difference between groups can be explained by the effects of the "offender" stigma within the school. The "offender" label, as it diffuses in the school environment, tend to create a negative expectation regarding those students, which would put them in a more vigilant situation, making them more vulnerable to more severe judgments about their behaviors and punishments (Bazon et al., 2013). Thus, it is possible to say that this mechanism would have a higher relation with the variable juvenile offenses, corroborating the model of inherent to the school control.

In this perspective, change a student's behavior through the frequent application of formal sanctions (warnings and suspensions), creates a maladaptation 
risk to the school environment, due to objective and subjective effects that negative labeling from teachers and peers, for example, can cause, and the rejection of school rules due to the negative feelings provoked by the eventual vexatious exposure associated with the sanction received. Maladaptation to the school environment increases the possibility of divergent/antisocial behaviors inside and outside of this institution of adolescent conduct control (LeBlanc, 1997, 2003). The specialized literature follows the same line, suggesting that the application of school sanctions tends to be more effective with students who do not present many behavioral problems. Those sanctions applied to students with disciplinary problems, tend to assert their behavior (Dewey, 2013; Cunha \& Dazzani, 2016).

It is likely that the most positive indicators regarding "performance" and "school bonding" presented by adolescents in I-Es acts as moderators of the negative impact of the sanctions suffered (as well as the experienced stress), helping them to remain linked to the school and the idea of schooling, according to the theoretical reasoning inherent to the school control system, remembering that the acceptance (and legitimation) of school sanctions is directly linked to the bonds established with the school. This group (O-S) also stood out positively, regarding the variable 'parental monitoring', which refers to the reaction of those responsible for the school results and the hypothesis of a possible abandonment of the studies. In the perception of the adolescents of this group, their parents/guardians would react more negatively to the possibility of school dropout. Therefore, it appears that they have parents who attribute a positive value to schooling and are more concerned with the task of supervising their children in academic activities if compared to those in O-Drop.

In summary, looking at the results together, considering the data from the four groups of adolescents studied, it can be said that all levels of vulnerability to educational problems, specifically school delays/ age-grade mismatch and low parental schooling/responsibility, this one more properly related to social determinants, like economic class, for instance. An increase in this panorama of vulnerability, which begins to differentiate the experience of these adolescents, is the resentful "stress" in the school environment. The higher their level, the higher the possibility of behavioral problems (avoidance and/or juvenile offense), as this is an additional adverse condition to conduct control in and by the school.
Beyond these context characteristics, it was pointed out that the mechanisms "performance" and "school bonding" are fundamental to the control of behavior, changing the experiences of adolescents, especially regarding to drop out of the school or not, while "constraints, "when these refer to the (often) experience of formal school sanctions, is also fundamental to controling behavior, differentiating the experience of adolescents, especially regarding the involvement in juvenile offenses. These would increase school maladaptation and divergent/antisocial behaviors inside and outside of the school. Apparently that school evasion per se, closely tied to poor performance and weak school ties, is a risk factor for committing juvenile offenses, insofar as other more specific risk factors that can be present for an adolescent, i.e., exposure to models and opportunities for infractions (Bazon et al., 2013, LeBlanc, 1996, 2006).

\section{Final Considerations}

School dropout and involvement in infractions during adolescence are two important problems that often appear and intertwine in the life trajectory of young people, with negative consequences for them and society. In the theoretical perspective adopted, based on numerous empirical research, with a longitudinal approach (LeBlanc, 1997; 2003; 2006), these can be understood by the prism of a systemic model, in which context variables and mechanisms are articulated and inter-influenced, to produce a control of adolescent behavior in and by the school, which subsidizes their experience of schooling. This perspective, although used in an exploratory way in the data analysis of Brazilian adolescents, allowed denoting the vulnerability of all to a negative school experience, besides observing and understanding the differences in the school experience of the investigated groups (offenders and non-offenders students, offenders and non-offenders who drop out of school), bringing to light the relevance of school performance and bonding for school perseverance/avoidance, and school constraints due to involvement in criminal activities. These thoughts can help to think about the actions to effectively (re) insert adolescents through the Justice System since this is an important dimension of the work to be carried out during the socio-educational follow-up.

Regarding the limitations of the study, it is important to highlight that the instrument MASPAQ School Scale used, has been only semantically adapted to the 
Brazilian socio-cultural reality. Although the data of the study itself offers some evidence of discriminant validity, considering the high degree of consistency between the results found and its theoretical basis, it will be important to carry out, shortly, specific psychometric studies, intending to their validation. Secondly, the fact that we did not have the deepest evaluation of the adolescents studied in terms of implication in infractional activities, since only official data were used in this study, care was taken to recruit who had passed through the Justice System to include in the offenders group (since they all complied with the socio-educational measure of Assisted Freedom during the research). In future research, however, the school experience of adolescents considering different levels of infractions, taking into account a "self-revealed delinquency" data, can be studied. In regard to this study limitations, it is important to note the reduced number of participants. In spite of the enormous challenge that the recruitment of participants in this field of study represents, future research can make efforts to work with more substantial and more diversified samples, to obtain results that can effectively subsidize public policies in the field.

\section{References}

ABEP (2010). Brazilian Association of Market Research Companies Brazil Economic Classification Criteria Recovered from http://www.abep.org/ novo/Content.aspx?ContentID $=139$.

Bazon, M. R., Silva, J. L., \& Ferrari, R. M. (2013). Trajetórias escolares de adolescentes em conflito com a lei. Educação em Revista, 29(2), 175-199. doi:10.1590/ S0102-46982013000200008

Calejon, L. M. C. (2017). Desempenho escolar e vulnerabilidade social. Revista Existus, 1(1), 149-164. Recovered from: http://www.ufopa.edu.br/ portaldeperiodicos/index.php/revistaexitus / article/view/214/201

Conselho Nacional de Justiça - CNJ (2012). Panorama nacional: a execução das medidas socioeducativas de internação. Recovered from: http://www.tjmt. jus.br/ intranet.arq/cms/grupopaginas/97/959/ Panorama_Nacional.pdf

Cornell, D. (2013). Prevention v. Punishment: threat assessment, school suspension, and racial disparities, 12. Recovered from: tps://www.justice4all. org/wp-content/uploads/2013/12/Prevention-vPunishment-Report-FINAL.pdf
Destro, C. M. A., \& Souza, L. A. P. (2012). Linguagem oral e escrita em adolescentes infratores institucionalizados. Revista CEFAC, 14(6), 1020-1027. doi: 10.1590/S1516-18462011005000089

Cunha, E. O., \& Dazzani, M. V. M. (2016). A escola e o adolescente em conflito com a lei: desvelando as tramas de uma difícil relação. Educação em Revista, 32(1), 235-259. doi:10.1590/0102-4698144008

Esterle-Hedibel, M. (2006). Absentéisme, déscolarisation, décrochage scolaire, les apports des recherches récentes. Déviance et Société, 30(1), 41-65. doi:10.3917/ds.301.0041.

Geib, C. F., Chapman, J. F., D’Amaddio, A. H., \& Grigorenko, E. L. (2011). The educationof juveniles in detention: policy considerations and infrastructure development. Learning and Individual Differences, 21(1), 3-11. doi: 10.1016/j.lindif.2010.05.002

Gomes, C. C., \& Conceição, M. I. G. (2014). Sentidos da trajetória de vida para adolescentes em medida de liberdade assistida. Psicologia em Estudo, 19(1), 4758. doi: 10.1590/1413-7372210860005).

Instituto Brasileiro de Geografia e Estatística - IBGE (2012). Recovered from: http://seriesestatisticas. ibge.gov.br/series.aspx?vcodigo $=$ SEE15

Jimenez, L. (2014). Você já está manjado: a saúde de adolescentes em conflito com a lei. Revista Psicologia Politica, 14(31), 535-549. Recovered from: http:// pepsic.bvsalud.org/pdf/rpp/v14n31/v14n31a08. pdf

LeBlanc, M. (1996). MASPAQ. Manuel et Guide d'utilisation. Montréal: Université de Montréal Press.

LeBlanc, M. (1997). La régulation sociale et personnelle de la conduite marginale. Manuel sur des mesures de l'adaptation sociale et personnel le pour les adolescents qué bécois. Université de Montréal, Montreal, 3-22.

LeBlanc, M. (2003). Traité de criminologie. Montréal: Université de Montréal

LeBlanc, M. (2006). Self-control and social control of deviant behavior in context:development and interactions along the life course. In Wikstrom, P. O. H., \& Sampson, R.J. (Orgs). The Explanation of Crime Context, Mechanisms, and Development. (pp. 124151). New York, CambridgeUniversity Press.

Li, Y., \& Lerner, R. M. (2011). Trajectories of school engagement during adolescence: implications for Psico-USF, Bragança Paulista, v. 23, n. 3, p. 437-449, jul./set. 2018 
grades, depression, delinquency, and substance use. Developmental Psychology, 47(1), 233-247. doi: $10.1037 / \mathrm{a} 0021307$

Mannheim, K. (1971). Sociologia Sistemática: uma introdução ao estudo de sociologia. São Paulo: Pioneira.

Sharkey, J. D., Shekhtmeyster, Z., Chavez-Lopez, L., Norris, E., \& Sass, L. (2011). The protective influence of gangs: Can schools compensate? Aggression and Violent Behavior, 16(1), 45-54. doi: 10.1016/j.avb.2010.11.001

Jimenez, L. (2013). A regulação da conduta delituosa pela escola: estudo comparativo entre adolescentes judiciarizados e não judiciarizados no contexto brasileiro. Dissertação de mestrado, Universidade de São Paulo, Ribeirão Preto, SP, Brasil.

Silva, J. L., \& Bazon, M. R. (2014). Educação escolar e conduta infracional em adolescentes: revisão integrativa da literatura. Psicologia em Estudo, 19(4), 278-87. doi: 10.1590/S1413-294X2014000400005
Silva, J. L., Cianflone, A. R. L., \& Bazon, M. R. (2016). School bonding of adolescent offenders. Paidéia, 26(63),91-100.doi:10.1590/1982-43272663201611

Xavier, J.M., \& Chaves, M. A. (2016). O estresse no processo educativo. Revista Saberes da Uniïpa, 4(4), 1-14. Recovered from: http://unijipa.edu.br/ revistas/artigos/103034

Zhang, D., Willson, V., Katsiyannis, A., Barrett, D., Ju, S., \& Wu, J. Y. (2010).Truancy off enders in the juvenile justice system: a multicohort study.Behavioral Disorders, 35(3), 229-242. doi: 10.1016/j. sbspro.2013.10.451

Zhang, L. (2011). Family, school and friends: correlates of Canadian youth outcomes. Child Indicators Research, 3(4), 467-98. doi:10.1007/s12187-010-9101-3

Recebido em: 05/09/2016

Reformulado em: 25/09/2017

Aprovado em: 07/11/2017

Sobre os autores:

Jorge Luiz da Silva, PhD in Public Health Nursing by Ribeirão Preto College of Nursing, University of São Paulo (EERP-USP). Professor of the Graduate Program in Health Promotion, Franca University (UNIFRAN).

E-mail: jorge.silva@unifran.edu.br

ORCID: https://orcid.org/0000-0002-3727-8490

Marina Rezende Bazon, PhD in Psychology by the Faculty of Philosophy, Sciences and Letters of Ribeirão Preto, University of São Paulo (FFCLRP-USP). Professor of the Graduate Program in Psychology at the Faculty of Philosophy, Sciences and Letters of Ribeirão Preto, University of São Paulo (FFCLRP-USP).

E-mail: mbazon@ffclrp.usp.br

ORCID: https://orcid.org/0000-0002-8037-8710

Contato com os autores:

Marina Rezende Bazon

Departamento de Psicologia da Faculdade de Filosofia, Ciências e Letras de Ribeirão Preto - USP

Av. Bandeirantes, 3900

Monte Alegre, Ribeirão Preto-SP, Brazil

CEP: 14040-901

Psico-USF, Bragança Paulista, v. 23, n. 3, p. 437-449, jul./set. 2018 